\title{
Sifting the Evidence for the Reconstruction of Pannonian Slavic ${ }^{*}$
}

\section{Ronald O. Richards' The Pannonian Slavic Dialect of the Common Slavic Proto-} Language, a revision of his UCLA Ph.D. dissertation, takes on the challenging task of wringing from the Hungarian-language evidence information on the Slavic dialect(s) that over time disappeared after the entrance of the Hungarians into the Carpathian basin in the ninth century AD. The difficulties Richards faces, as have others before him, are formidable. Although the corpus of borrowed Slavic material in Hungarian is not small - altogether some 1500 lexical items - the time and locus of borrowing are difficult if not, in some cases, impossible to pin down because (a) some lexical items may have entered during a period of prior Slavic-Hungarian contact, and (b) some degree of Slavic-Hungarian contact has remained in effectvirtually to the present day-even after the geographical continuity of the Slavic speech territory in the north and south was severed. To complicate matters further, the Slavic speech territory during the period under scrutiny was undergoing an exceptionally dynamic phase of expansion and internal differentiation. Additionally, Sprachbund phenomena coupled with the lengthy time parameter along which Slavic material has been deposited in Hungarian have contributed to multifarious transformations of the material, making it difficult to determine whether variation found in the borrowed Slavic material is to be attributed to Slavic dialect differentiation or to internal Hungarian developments. In principle the Sprachbund phenomena could be sorted out better if the Hungarians had left some close (surviving) relatives behind during their migration into Europe. As it stands, the closest linguistic relatives, Khanty and Mansi, who make up the Ob-Ugric group, separated from Proto-Hungarian some three millennia ago, making this avenue of investigation virtually meaningless. The ambiguities and internal contradictions in the Slavic borrowed material in Hungarian have led previous investigators to conflicting assessments.

As is common in this genre, the work is embedded in a tradition of drawing conclusions, both explicit and implicit, on the "ethnogenesis" of the peoples in

* Review of Ronald O. Richards, The Pannonian Slavic Dialect of the Common Slavic Proto-Language: The View from Old Hungarian. UCLA Indo-European Studies, vol. 2, eds. Vyacheslav V. Ivanov and Brent Vine, Los Angeles: UCLA, Program in Indo-European Studies, 2003. xxvii, 234 pp. Bibliography. Index Verborum. \$12.00, paper. 
question, a tradition that is especially fraught with extravagant claims and unpleasant connotations in the European context (for a review of the issues see, for example, Curta 2002, Mees 2003). For this reason, works that are honest and explicit about their epistemological underpinnings are particularly called for. In this regard, Richards' book is a refreshing departure in that it continually questions the knowability of the details of the past. Commendably, the author takes great pains to explain how he comes to the conclusions that he does. He likens his approach to the arduous and somewhat unaesthetic process of mining particulate minerals, which only after several stages reveals wealth from the rocks and soil (xiv) (perhaps "Panned Slavic?")

The book is divided into four chapters: (1) Introduction (1-48), treating previous views of the settlement history, focusing in particular on the problem of the Avar-Slavic relationship and the surmised ethnolinguistic composition of Slavicspeaking Pannonia until the arrival of the Magyars; (2) Methodologies (49-88), including sketches and discussion the problems of both the Slavic and Hungarian phonological systems, as well as consideration of semantic factors, of the relevant periods as means of identifying Pannonian vs. non-Pannonian Slavic loanwords; (3) Examining the Corpus (89-190), a lexeme-by-lexeme examination of the Pannonian-Slavic loanwords; and (4) Conclusion (191-214). A Selected Bibliography (215-228) and an Index Verborum (229-234) are also included.

In the Introduction Richards attempts to model the succession of settlement in the Carpathian Basin using non-linguistic evidence as a background to the linguistic analysis. Crucial for his understanding the dynamics of the pre-Magyar population is the nature of the relationship between Slavs and Avars. He assesses this relationship both from the viewpoint of Slavic- and Avar-focused traditions of scholarship and employs Nichols" concept of "spread-zone" to explain alleged successive displacements. He concludes that although little can be said about the relationship of the Avars and Slavs linguistically, the fact that center-periphery phenomena are observed suggests that the Avars are the most likely candidates for having triggered the Slavic expansion (209).

Richards uses datable changes in phonology in either Slavic or Hungarian as criteria to determine the chronology of Slavic borrowing, where borrowings that can be dated prior to the $12^{\text {th }}$ century are considered Pannonian Slavic; otherwise they are non-Pannonian Slavic and can be associated with other (extant) Slavic dialects. The diagnostic changes are as follows:

1. Preserved nasals are thought to indicate borrowings dating at the latest to the twelfth century on the assumption that the loss of nasals in Slovak and SerboCroatian, other more-or-less central Slavic languages, began around the $10^{\text {th }}$ century, e.g., S1 *ręd b > Hu rend 'order, row' was borrowed earlier, S1 * pęta> Hu pata 'heel' later $(50-51,56)$. 
2. Substitution of $\mathrm{Hu} \breve{c}$ or $t$ for Slavic $c$ indicates borrowing prior to the development of $\mathrm{Hu} c$ no earlier than the $11^{\text {th }}$ century. Thus $\mathrm{S} 1 *$ cévb $>\mathrm{Hu} c s o ̋$ 'pipe, tube', Slavic *nèmbcb > Hu német 'German' are earlier; *lanbcb > lánc 'chain' is later (51-52).

3. As Hungarian lacked the sound $\check{z}$ until the $11^{\text {th }}$ century, substitution of voiceless $\check{s}$ for Slavic $z$ indicates Pannonian lexicon, e.g., S1 *kъnęz'a (Richards writes $K n e ̨ z ̌ a$, evidently assuming loss of the jer and merger of $*_{z j}$ with $\left.\check{z}\right)>\mathrm{Hu}$ Kenese (52) is earlier; *žaba > zsába 'frog' is later (56).

4. Loss of jers in Pannonian Slavic, dating to between the $9-10^{\text {th }} \mathrm{cc}$., would imply that borrowed preserved jers indicate early borrowings. However, as Richards points out, a similar process of the elimination of short high vowels was occurring at the same time in Hungarian, thus removing the reflexes of a borrowed "weak" jer. Nevertheless, an example such as retek 'radish' < * redbky, which displays regressive voicing assimilation characteristic of the post-jer-fall state, indicates a later borrowing (53-54; see also Xelimskij 1988: 354). This is an excellent example of the probative value of analyzing the relationship among innovations rather than innovations seen as isolated events Although Richards rightly points out that examples such as Hu rák 'crab, crayfish', máz 'glaze, coating', and even phonotactically assimilated barát 'friend' ( $<\mathrm{S} 1$ *brätrъ), ebéd 'lunch' ( $<\mathrm{Sl}$ *obë'd ), contain segments present in both early Slavic and Hungarian, it is not true that such examples are useless, as he asserts, in establishing chronology of borrowing. At a minimum, when suprasegmental information is taken into account, these forms show that the borrowings occurred at a point prior to the shortening of the "old acute" stress in originally long vowels, characteristic of (at least) South Slavic after the eighth century. Furthermore, a later West Slavic borrowing can be ruled out, given that compensatory lengthening failed in final closed syllables to yield the characteristic West Slavic length associated with the old acute, e.g., Czech brat, obéd; Slovak brat, obed. There is no reason, therefore, to exclude such examples from the "Pannonian Slavic" corpus. On the contrary, these examples give valuable evidence that at the time of borrowing, Slavic "old acute" stress was still realized as a long vowel. In addition, as Xelimskij has discovered, Hungarian vowel harmony is determined by the identity of the stressed vowel in the donor word, hence such examples as $\mathrm{S} 1{ }^{*}$ ob $\ddot{d} d b>e b e ́ d$ attest not only the archaic length but also placement of stress (1992). Granted, these facts about Proto-Slavic are recoverable through comparative reconstruction, but Hungarian has essentially "fossilized" the Slavic material in its pristine state, corroborating the reconstruction.

Having delimited the corpus of "Pannonian Slavic," Richards then attempts to assign the borrowed lexemes, one by one, to a predetermined schema of Slavic 
dialects assumed for the relevant period, a schema adopted from Birnbaum 1966. The six dialects are labeled A-F with subscripts for pertinent sub-dialects (175):

\begin{tabular}{lll}
\hline $\mathrm{A}_{1}$ & East Slavic & Non-Proto-Novgorodian \\
\hline $\mathrm{A}_{2}$ & East Slavic & Proto-Novgorodian \\
\hline $\mathrm{B}$ & Lekhitic & \\
\hline $\mathrm{C}$ & Sorbian & \\
\hline $\mathrm{D}_{1}$ & Czechoslovak & Proto-Czech \\
\hline $\mathrm{D}_{2}$ & Czechoslovak & Proto-Slovak \\
\hline $\mathrm{E}_{1}$ & Sloveno-Serbocroatian & Proto-Slovene \\
\hline $\mathrm{E}_{2}$ & Sloveno-Serbocroatian & Proto-Serbocroatian \\
\hline $\mathrm{F}_{1}$ & Macedo-Bulgarian & Proto-Macedonian \\
\hline $\mathrm{F}_{2}$ & Macedo-Bulgarian & Proto-Bulgarian \\
\hline
\end{tabular}

Richards conveniently reproduces the table in the headers of pp. 118-189, which allows the reader to refer to the A-F labels throughout the analysis of the corpus. The goal is then to decide on a lexeme-to-lexeme basis to which of the proto-dialect entities each lexeme could be plausibly assigned, based on matches of known segmental innovations and semantic criteria. The corpus is then surveyed for statistical trends that will allow a probabilistic assignment to one or another of the proto-dialects.

In the Conclusion the author boils the evidence down to three possible scenarios to which he attempts to assign degrees of probability: (1) If the Pannonian Slavic speech territory was homogeneous, then "it is most likely that this dialect was associated with, or an extension of, Proto-Serbocroatian" (191). (2) If Pannonian Slavic was heterogeneous, then "it is most likely that this dialect(s) was associated with, or an extension of, Proto-Serbocroatian and Proto-Czechoslovak, while association with the Proto-Sorbian or Proto-East Slavic dialect groups would remain possible but not probable" (191). (3) "Pannonian Slavic existing as a homogeneous entity with a linguistic profile associated with, or as an extension of, Proto-Slovene, is very unlikely" (191).

To decide on the best of the "possible" permutations, Richards elaborates a scenario in which the Avar/Hungarian entrance in the Carpathian basin displaces the Slavs northward and southward. He regards the central-Slovak South-Slavic features as an intrusion that attests to a disruption in the continuum.

Here I find it difficult to agree with Richards' methodology, as it seems to me that if choosing an affinity for Pannonian Slavic with a predetermined set of "known" dialects of Common Slavic is the goal, then the results will not be very illuminating. For one thing, we cannot be very sure about the features, 
sociolinguistic situations, and alleged past boundaries of these proto-dialects, especially of such dubious constructs as "Proto-Serbocroatian," a notion that has more to do with the $19-20^{\text {th }}$ centuries than it does with the 9-10 $0^{\text {th }}$. Because we know little about what Pannonian Slavic was like except through indirect evidence of the type that is fossilized or distantly reflected in Hungarian, or in the rare scattered textual and dialectological evidence that can be associated at least peripherally with the area, then we must be open to the notion that the Pannonian Slavic area may have had its own style of speech and hence we can at least entertain the possibility that Pannonian constituted a "dialect" in its own right. The evidence suggests that this is the case: an examination of circum-Pannonian dialect situation reveals that certain of the dialect groupings cited in Birnbaum's A-F do not correspond to reality. A crucial piece that fails to fit into this schema is the central Slovak dialect, spoken to the north of the Hungarian speech territory, which in a number of ways corresponds to features found in South Slavic dialects, today spoken to the south of Hungarian, and contrasts with both the Slovak dialect areas to the west and east of it, which are more like each other than like central Slovak. In addition to the arguably static list of "Yugoslavisms," South Slavic features left "stranded" in central Slovak (a review of these, with excellent maps, can be found in Krajčovič 1974: 142-149; 314-318), one can also observe innovations that continued in a parallel fashion even after a continuous Slavic speech territory between today's South Slavic and central Slovak ceased to exist. One of these is the tendency for strong jers to centralize and lower in long (or lengthened) syllables, in the context of the "neo-acute" (stressed, rising) in central Slovak and in the context of the "circumflex" (stressed, falling) in South Slavic (for details see Greenberg 1988). Another is what I have argued is a retention feature, the roundedness of ProtoSlavic * $a$, characteristic of northern and eastern Slovene dialects and Kajkavian, which prevented mergers with strong jers characteristic of the western half of South Slavic (see Greenberg 1998 and 2000: 65ff for details). Still another is the retention of length in mobile ("c"-stressed) present tense forms of $e$-stem verbs, found in Carinthian and Prekmurje Slovene (north-west and north-east, respectively) and central Slovak (see Vermeer 1984; Greenberg 2000: 93). In my view, these circumPannonian features are the afterglow of Pannonian Slavic. Whether archaic or innovative, these features contributed to the style of speech that was characteristic of the Pannonian Slavic speech community.

Richards interprets this information differently, positing a scenario derived from Nichols' model of expansion that assumes displacement of peoples and their speech communities. He says: "While South Slavic features found in the Central Slovak dialect cannot directly answer the question of Proto-Slovene vs. ProtoSerbocroatian, they can provide strong evidence in favor of a South Slavic linguistic profile for Pannonian Slavic. Regardless of whether it was the Avars who forced 
Slavs out of the Carpathian Basin/Pannonia, or the Hungarians, or some combination thereof, if we see South Slavic elements so strongly in Central Slovak, this would argue that the entire Carpathian Basin/Pannonia was South Slavic, or at least predominantly South Slavic. Obviously if the Avars/Hungarians came into this area, their effect would have been to displace Slavs not just northward to the Slovak language area, but also south to the Proto-Serbocroatian language area" (my emphasis; 203-204).

Richards' view of Pannonian Slavs as "displaced," though it reiterates many earlier speculations, contradicts the view of the Slavic-Hungarian relationship as a symbiosis, a view supported by at least two substantial sets of facts: (1) the archaeological evidence, which indicates a trend toward common burial rituals and sites and, implicitly, intensive and intimate ethnic interaction over several centuries (see Xelimskij 1988: 351 and works cited there); and (2) the considerable Slavic linguistic material in Hungarian, which can be best explained by the implications derived from the archaeological evidence just mentioned, i.e., that the contact was intensive, extensive, and long-lasting. In other words, even if the Hungarian presence created a Slavic refugee crisis, there were apparently many Slavs who remained behind to impart knowledge of the natural world and Slavic lifeways as evidenced by the borrowings that reflect these fields. A modern typological parallel to what likely took place in the Slavic-Hungarian symbiosis can be observed in the multilingual speech community at Fort Chipewyan, a town of 1500 people in which coexistence and convergence among four languages-Cree, French, English, and Chipewyan - has gone on for over a century. It is not unusual for conversations among Fort Chipewyan community members to take place in three of these languages, yet it is also clear that the use of four languages is converging towards English, which is at the same time becoming transformed by the sociolinguistic processes (Scollon and Scollon 1979).

A key argument in Richards' exposition is that the large number of borrowings with a back nasal vowel, once the historical Hungarian vowel downshift is removed, point to the phonetic value of Pannonian Slavic ${ }^{*} Q$ as $[u]$ (169ff). This proposed value in itself is not too controversial. While admitting that this phonetic value is not necessarily diacritic with respect to Proto-Slavic dialects, he nevertheless elects to view it as a diacritic feature that points away from Proto-Slovene and towards Proto-Serbocroatian (173-174). Although he quotes me as saying that an $o$-reflex is a diacritic archaism found in Slovene (206-207), I am not very comfortable with the notion that so pivotal an argument in Richards' case is built on this speculation.

* I am grateful to Henning Andersen who in another context brought this work to my attention and pointed out the possibility of gaining insight from it into the reconstruction of Slavic. 
Even if I am right about the value of Proto-Slovene ${ }^{*} Q$, a single reflex does not make a speech community. Secondly, identifying vowel qualities in nasalized syllables is risky business, as nasalization is notorious for obscuring vowel quality. The uncertainty is only compounded when it is considered that the vowels in question were transferred through imperfect acquisition from $L_{1}$ to $L_{2}$.

I applaud Richards for tackling this extraordinarily complex problem. Although I disagree with the work on several points, matters that are largely a question of interpretation, I admire its honest articulation of methodology and careful, even cautious, treatment of facts. Scholars interested in the linguistic prehistory of Central Europe will want to read this book and carefully consider its arguments in order to approach a deeper appreciation of Slavic-Hungarian contact.

University of Kansas

\section{REFERENCES}

Birnbaum, Henrik. 1966. "Dialects of Common Slavic," Ancient Indo-European Dialects. eds. Henrik Birnbaum and Jaan Puhvel, Berkeley and Los Angeles: University of California Press. 153-197.

Curta, Florin, 2002. "From Kossina to Bromley: Ethnogenesis in Slavic Archaeology," On Barbarian Identity. Critical Approaches to Ethnicity in the Early Middle Ages. ed. Andrew Gillett, Studies in the Early Middle Ages, v. 4, Turnhout, Belgium: Brepols. 201-218.

Greenberg, Marc L. 1988. "On the Vocalization of Jers in Slovak," Die Welt der Slaven 33: 43-62.

. 1998. "Vatroslav Oblak and Early Innovations in the South Slavic Vocalic Systems," Vatroslav Oblak. Mednarodni simpozij Obdobja. Ljubljana, 12. in 13. December 1996. ed. Alenka Šivic-Dular, Ljubljana: Filozofska fakulteta. 101-110. 2000. A Historical Phonology of the Slovene Language. Historical P honology of the Slavic Languages, Bd. 13, ed. Paul Wexler, Heidelberg: Universitätsverlag Carl Winter.

Kniezsa, István. 1974. A magyar nyelv szláv jövevényszavai. vołs. 1-2, Budapest: Akadémiai Kiadó.

Krajčovič, Rudolf. 1974. Slovenčina a slovanské jazyky I. Praslovanská genéza slovenčiny. Bratislava: SPN.

Mees, Bernard. 2003. "Stratum and Shadow: A Genealogy of Stratigraphy Theories from the Indo-European West," Language Contacts in Prehistory Studies in Stratigraphy. Papers from the Workshop on Linguistic Stratigraphy and Prehistory at the Fifteenth International Conference on Historical Linguistics, Melbourne, 17 August 2001. Current Issues in Linguistic Theory 239, ed. Henning Andersen, Amsterdam: John Benjamins. 11-44.

Nichols, Johanna. 1993. "The Linguistic Geography of the Slavic Expansion," American Contributions to the Eleventh International Congress of Slavists. Literature. Linguistics. Poetics. eds. Robert A. Maguire and Alan Timberlake, Columbus, $\mathrm{OH}$ : Slavica. 377-391. 
Scollon, Ronald and Suzanne B. K. Scollon. 1979. Linguistic Convergence. An Ethnography of Speaking at Fort Chipewyan, Alberta. New York, San Francisco, London: Academic Press.

Vermeer, Willem R. 1984. "On Clarifying Some Points of Slavonic Accentology: The Quantity of the Thematic Vowel in the Present Tense and Related Issues," Folia Linguistica Historica 5.2: 331 -395.

Xelimskij, Evgenij A. (Eugene Helimski). 1988. "Венгерский язык как источник для праславянской реконструкции и реконструкции славянского языка Паннонии," Славянское языкознание. Х Международный съезд славистов. София, сентябрь 1988 г., Доклады советской делегачии. ed. N.I. Tolstoj, Moskva: Nauka. 347-368.

1992. "Slavic/Latin/German Stress and Hungarian Vowel Harmony," Finnischugrische Sprachen zwischen dem germanischen und dem slavischen Sprachraum. eds. László Honti, et al., Amsterdam/Atlanta: Rodopi. 45-54. 